\title{
Effect of Welding Current on Mechanical Properties of Welding Joints in S235JR(Cu) Steel Sheets in Resistance Spot Welding
}

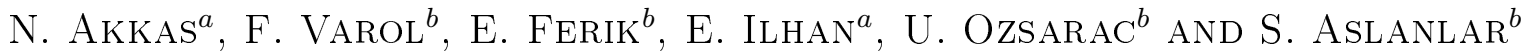 \\ ${ }^{a}$ Sakarya University, Faculty of Technology, Department of Mechanical Engineering, 54187, Sakarya, Turkey \\ ${ }^{b}$ Sakarya University, Faculty of Technology, Department of Metallurgical and Materials Engineering \\ 54187, Sakarya, Turkey
}

This paper presents an experimental study on resistance spot welding of $\mathrm{S} 235 \mathrm{JR}(\mathrm{Cu})$ steel sheets used in side wall and roof in rail vehicles. $\mathrm{S} 235 \mathrm{JR}(\mathrm{Cu})$ steel sheets having $2.0 \mathrm{~mm}$ thicknesses were joined by using resistance spot welding as lap joint. A timer and current controlled resistance spot welding machine having $120 \mathrm{kVA}$ capacity and a pneumatic application mechanism with a single lever was used to prepare the specimens. Welding periods were chosen as 10,15,20,25 and 30 cycles and also welding currents were increased from $6 \mathrm{kA}$ up to $14 \mathrm{kA}$ by rise of $1 \mathrm{kA}$. The electrode force was kept constant at $6 \mathrm{kN}$. The prepared welding specimens were exposed to tensile-shear and tensile-peel tests and the obtained results were supported by diagrams and, finally, appropriate welding parameters were advised to the users.

DOI: 10.12693 /APhysPolA.125.500

PACS: $81.20 . \mathrm{Vj}$

\section{Introduction}

Resistance spot welding (RSW) is an efficient joining process widely used for the fabrication of sheet metal assemblies. RSW has excellent techno-economic benefits such as low cost, high speed and suitability for automation which make it an attractive choice for auto-body assemblies, truck cabins, rail vehicles, and home appliances [1]. The process is used extensively for joining of low carbon steel components. After spot welding, important changes occur in mechanical and metallurgical properties of the spot welded areas and heat affected zones. The investigation of these changes is very important for the safety strength of the welded joints [2]. Therefore, in this study the relationship between welding current and tensile strength of joint in $\operatorname{S} 235 \mathrm{JR}(\mathrm{Cu})$ in $\mathrm{RSW}$ was investigated.

\section{Experimental studies}

The materials studied are $\operatorname{S} 235 \mathrm{JR}(\mathrm{Cu})$ steel sheets having $2.0 \mathrm{~mm}$ thicknesses, and used in rail vehicle bodies. The chemical composition and the mechanical properties of the sheet are shown in Tables I and II, respectively.

Chemical composition of steel sheets

TABLE I used in experiments (wt\%)

\begin{tabular}{c|c|c|c|c|c|c|c|c|c}
\hline \hline $\mathrm{C}$ & $\mathrm{Si}$ & $\mathrm{Mn}$ & $\mathrm{P}$ & $\mathrm{S}$ & $\mathrm{Cr}$ & $\mathrm{Ni}$ & $\mathrm{Mo}$ & $\mathrm{Al}$ & $\mathrm{Cu}$ \\
\hline
\end{tabular}

\begin{tabular}{l|l|l|l|l|l|l|l|l|l}
\hline 0.0902 & 0.164 & 0.513 & 0.0149 & 0.0063 & 0.0183 & 0.0481 & 0.0068 & 0.0349 & 0.273
\end{tabular}

TABLE II

Mechanical properties of the sheet steel.

\begin{tabular}{c|c}
\hline \hline yield strength [MPa] & 320 \\
tensile strength [MPa] & 435 \\
total elongation [\%] & 52
\end{tabular}

The fracture must be observed in welding zones of tensile-shear and tensile-peel testing specimens. In addition, side effects should be prevented and minimum materials waste was aimed. These factors were evaluated in designing sizes of test specimens. A timer and current controlled electrical resistance spot welding machine having $120 \mathrm{kVA}$ capacity and a pneumatic application mechanism with a single level were used in experiments. The electrode force was continuously measured and controlled during the experiments. Welding was carried out by using a water cooled conical $\mathrm{Cu}-\mathrm{Cr}$ electrodes having a contact surface of the same diameter $(7 \mathrm{~mm})$. In addition, welding current values were calculated and controlled by means of a current transformer which is set on upper level of welding machine and an amperemeter continuously. Weld time, hold time and clamping time were adjusted automatically by electronic devices of the welding machine.

The specimens are prepared as shown in Fig. 1 and cleaned ultrasonically. After that, these parts were overlapped with $30 \mathrm{~mm}$ spacing and welded. The electrode force was fixed at $6 \mathrm{kN}$ and controlled during experiments. The welding time was applied as 5, 10, 15, 20, 25 , and 30 cycles $(1$ cycle $=0.02 \mathrm{~s}$ ). Clamping and hold times were remained constant as 25 cycles in all series. The welding current was increased from $6 \mathrm{kA}$ to $14 \mathrm{kA}$ by $0.5 \mathrm{kA}$ increments. The welded parts were exposed to tensile-shear and tensile-peel tests in a testing machine in laboratory conditions. The tensile speed was remained constant during test. The values given as tensile-shear and tensile-peel strength are the maximum values read from the scale of the machine.

During the tests, three types of breaking failures were observed: (1) separation, (2) knotting, and (3) tearing. Samples of them were shown in Fig. 2. 


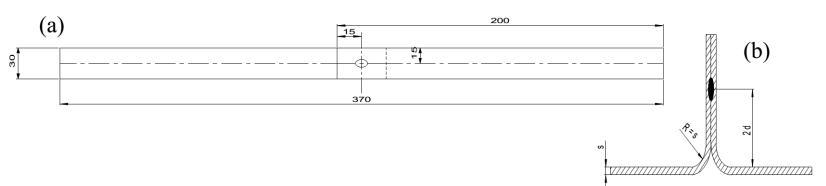

Fig. 1. The dimensions of the tensile-shear specimens (a), and the tensile-peel specimens (b).
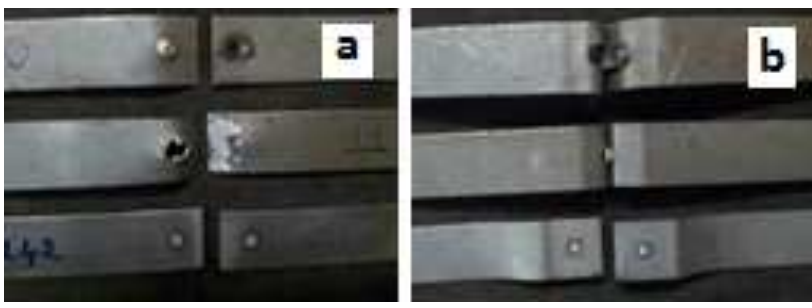

Fig. 2. Breaking failure samples observed in (a) tensile-shear, and (b) tensile-peel tests.

\section{Results and discussion}

3.1. Effect of welding current on tensile-shear strength

In low welding current application, small weld nugget diameters were obtained and similarly lower tensile-shear strength value than that of base-metal was measured due to low heat application to welding zone. As a result, break type was observed as separation. However, the tensile-shear strength increases with increasing weld current.

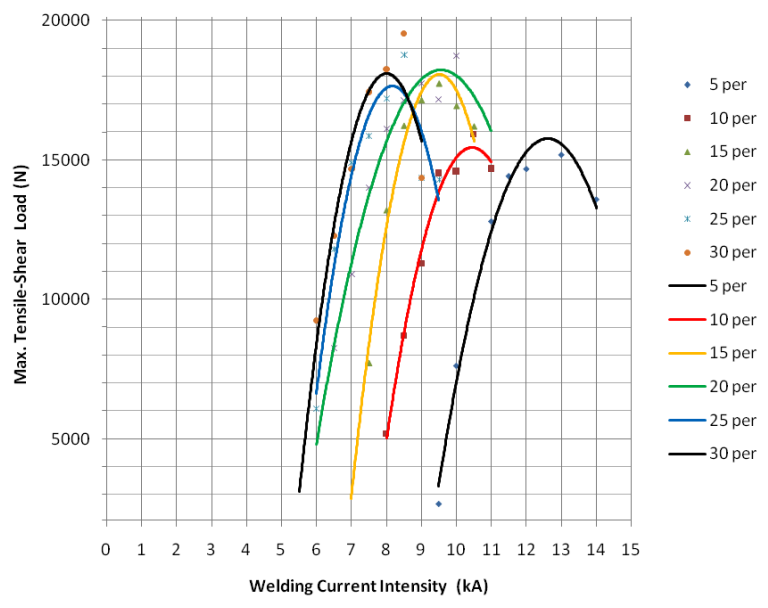

Fig. 3. Effect of welding current on tensile-shear strength of weld joints.

This situation is depicted in Fig. 3. So, break type was observed as knotting. In long welding time and high welding current application, cross-section area decreases, as a result, tensile-shear strength of joint decreases. Electrodes react to work piece due to excessive heating of them which cannot be compensated by cooling water. In addition, weld nugget spurts out between two sheets resulting in the decrease in diameter.
This may be a reason for decreasing trend of tensile-shear strength as shown in Fig. 4. At the same time, an over-colored, retained structure with deep electrode marks and deformations was determined in weld zone.

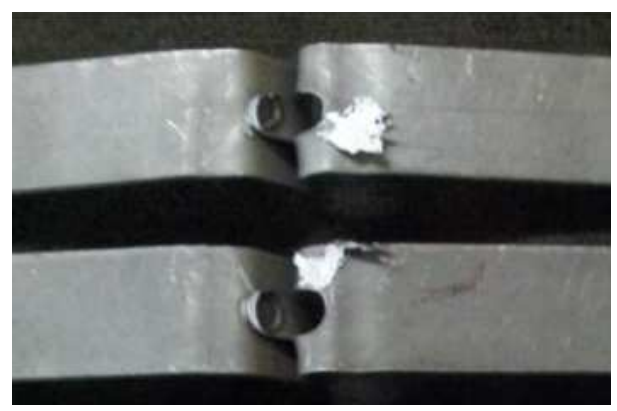

Fig. 4. Spurt out failure observed in weld nuggets of workpieces.

Results of tensile-shear tests.

TABLE III

\begin{tabular}{c|c|c}
\hline \hline $\begin{array}{c}\text { Welding time } \\
\text { [per] }\end{array}$ & $\begin{array}{c}\text { Welding current } \\
{[\mathrm{kA}]}\end{array}$ & $\begin{array}{c}\text { Max. tensile- } \\
\text {-shear load [N] }\end{array}$ \\
\hline 5 & 13 & 15181 \\
10 & 11 & 15909 \\
15 & 9.5 & 17740 \\
20 & 10 & 18746 \\
25 & 8.5 & 18773 \\
30 & 8.5 & 19535
\end{tabular}

The measured tensile-shear strength values in 5, 10, 15, 20,25 , and 30 cycles were tabulated in Table III above. The values in 5 cycles were lower than that of $10,15,20$, 25 , and 30 cycles. The maximum point was reached in 30 cycles for $8.5 \mathrm{kA}$ current ranges.

\subsection{Effect of welding current on tensile-peel strength}

In low welding current and short time application, small weld nugget diameters were obtained and similarly lower tensile-shear strength value. As a result, break type was observed as separation. However, the tensile-shear strength increases with increasing weld current. This situation is depicted in Fig. 5. Breaking failure modes detected in tensile-shear tests change from separation to knotting, tearing from the weld nugget and tearing from the base-metal with the increasing welding current.

Results of tensile-peel tests.

TABLE IV

\begin{tabular}{c|c|c}
\hline \hline $\begin{array}{c}\text { Welding time } \\
{[\mathrm{per}]}\end{array}$ & $\begin{array}{c}\text { Welding current } \\
{[\mathrm{kA}]}\end{array}$ & $\begin{array}{c}\text { Max. tensile- } \\
\text {-shear load [N] }\end{array}$ \\
\hline 5 & 12 & 2725 \\
10 & 11 & 3748 \\
15 & 10 & 4915 \\
20 & 9 & 5950 \\
25 & 8.5 & 5040 \\
30 & 8.5 & 5748
\end{tabular}




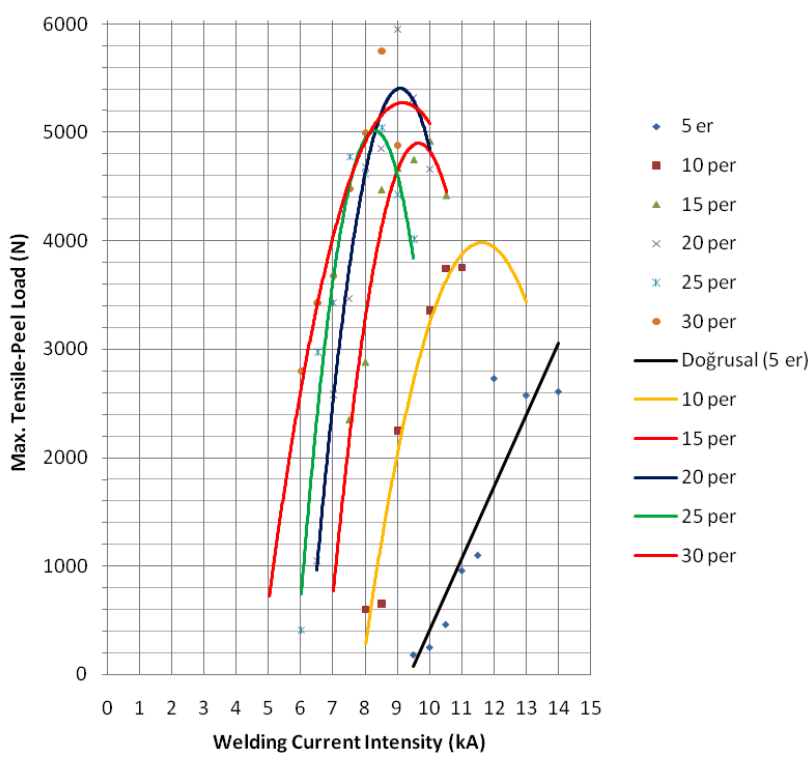

Fig. 5. Effect of welding current on tensile-peel strength of weld joints.

Maximum tensile-peel strength value was gained in 30 cycles at approximately $8.5 \mathrm{kA}$ welding current. The measured tensile-peel strength values in 5, 10, 15, 20, 25 and 30 cycles are tabulated in Table IV.

\section{Conclusion}

$\operatorname{S235JR}(\mathrm{Cu})$ grade steel sheets which are known as non-alloy steels for structural purposes and widely used in the petroleum, petrochemical, water conservancy, electric power, food, brewing, shipbuilding, marine engineering and rail transportation were used in this study. The effect of welding current on tensile properties of weld joints in resistance spot welding of these steels was investigated and the following conclusions were drawn: the optimum tensile-shear strength value of S235JR $(\mathrm{Cu})$ steel sheets was obtained in $9.5 \mathrm{kA}$ welding current for $20 \mathrm{cy}-$ cles welding time. When the surface quality is required, two alternatives become valid; one is $8 \mathrm{kA}$ welding current in 30 cycles and the other is $8.5 \mathrm{kA}$ welding current in 25 cycles. The optimum tensile-peel strength value of resistance spot welded $\operatorname{S235JR}(\mathrm{Cu})$ steel sheets was obtained in $8.5 \mathrm{kA}$ welding current for 20 cycles welding time. This value is approximately $30 \%$ of tensile-shear strength.

\section{Acknowledgments}

The authors wish to thank Sakarya University Scientific Research Foundation (project number: 2010-05-04-004) for their support.

\section{References}

[1] S. Aslanlar, A. Ogur, U. Ozsarac, E. Ilhan, J. Mater. Des. 29, 1427 (2008).

[2] M. Vural, A. Akkus, J. Mater. Proc. Technol. 153154, 1 (2004). 